\title{
Gender Equality and the Intersectional Turn
}

\section{AF THORgERDUR EINARSDOTTIR OG ThORgerdur THORVALDSDOTTIR}

Equal opportunity work is curvently being transformed from one-sided emphasis on gender equality, to a broader notion of diversity, or human rights issues. But are the equality tools needed by the diverse disadvantaged groups sufficiently similar? Can (gender) mainstreaming, for instance, be expanded to include other diversity issues, or will "diversity mainstreaming” just be a watered out version?

The article is based on a paper entitled "Equality Discourses at Crossroads. Gender Equality vs. Diversity" which was presented at The 6th European Gender Research Conference. Gender and Citizenship in multicultural context. University of Lodz, Poland, August 31st-September 3rd 2006. A longer version of the paper has been translated into Polish for a publication in a Lodz conference book and it is now being reviewed for a publication in a conference book in English as well.

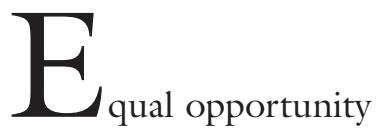

work is currently being transformed from one-sided emphasis on gender equality to a broader notion of diversity, or human rights issues. This new approach has both problems and potentials. Although most people agree with the goal of equal opportunities for all, there is a growing tension between those who associate the concept of "equal rights" first and foremost with gender equality, and those who want to relate it to broader struggles against any kind of structural inequalities. This tension touches upon some fundamental questions regarding the very nature of equality work and the usefulness of different equal opportunity strategies. Are the equality tools needed by the diverse disadvantaged groups sufficiently similar, for them "to share institutional spaces" (Walby 2004) and an overreaching "one size fit all" (Verloo 2006) equality strategy? Can (gender) mainstreaming, for instance, be expanded to include other diversity issues, or will "diversi- 
ty mainstreaming" just be a watered out version? (Woodward 2004, Walby 2004, Squires 2005, Shaw 2005, Verloo 2001, 2006).

The article starts by exploring recent theoretical debates on intersectionality and gender equality. It then addresses problems and potentialities of the emerging 'equality for all' policies, drawing upon empirical examples from equality work in Iceland. Practical equality work will be viewed through the lenses of feminist theories on intersectionality and related to wider political context and gender discourse in Iceland. Open interviews with eleven, differently located, equal opportunity workers in Iceland will be read in connection with the opinions of representatives from various minority groups in Iceland which have spoken publicly on the issue. Finally, equality work at the city of Reykjavik and the University of Iceland, both of which have been in the forefront in expanding the equality concept, will be investigated. These empirical examples will be analyzed in light of the theoretical background, in particular, the different models, discussed by Verloo (2006) and Squires (2005) regarding how practical equality work can be dealt with. By bringing together theory and praxis, we hope to shed light on some of the problems and possibilities that are bound up with the different approaches.

\section{FEMINIST THEORIES OF INTERSECTIONALITY}

The term, intersectionality, was first introduced by Crenshaw in 1989, as an intervention to traditional "identity politics" (Crenshaw 1994:179). Nevertheless, the genealogy of intersectional thinking has a much longer history within the feminist tradition (Lykke 2005, Brah \& Phoenix 2004, Collins 1998). While identity politics tended to look at different categories in isolation, focusing on the uniqueness of each, intersectionality explores how these systems mutually construct one another,
(Crenshaw 1994, Yuval-Davis 2006). Following feminist physicist and philosopher Karen Barad (Barad 2003) Lykke emphasizes the importance of looking at how different sociocultural categories, such as gender, ethnicity, race, class, sexuality, age/ generation, nationality etc. 'intra-act', and mutually transform each other, while interplaying as opposed to 'inter-act', or classing against one another without initiating mutual transformation (Lykke 2005: 8).

Verloo (2006) who draws upon Crenshaw's (1989) distinction between 'structural' and 'political' intersectionality, where structural intersectionality refers to experiences of inequalities, and political intersectionality refers to how intersections of inequalities relate to political strategies, for example, how and when feminism and gender equality politics marginalize ethnic minorities, disabled women or lesbians. Verloo attempts to clarify the debate by systematically focusing on similarities and differences of different inequalities, such as their origins, how they are reproduced, and what goals and political strategies are relevant in each case. Another important insight is Knapp's (2005) insistence on the need to extend intersectional analysis from the micro to the macro level, which enables feminist scholars to question how "gender relations and heteronormative sexuality, class relations and configurations of ethnicity and race/ism [are] interwoven in the structural and institutional make-up of a given society $[\ldots]$ And what happens to these relationalities under conditions of social, political and economic transformations?" (Knapp 2005, 259.) Similarly, Yuval-Davis (2006) addresses the need to distinguish between different levels of differences. She is responding to a tendency in the current debate to conflate different levels together and reduce them to one. Notwithstanding Butler's insight that the classification of social divisions is a continuously contested human product (Butler 1990), she argues that social divisions operate on many levels, 
in specific historical contexts and conditions, some are macro axes of social power and others are subjective experiences, some of which may be more important than others (Yuval-Davis 2006). She suggests that different levels of social divisions should be examined separately, and after that an intersectional review, or dialogue, of policy initiatives and systems of implementation should be undertaken. Such a dialogue, should involve policy-makers, feminist scholars and people on the ground, i.e. from women's movements and various minority group organizations, hence, the three pillars needed in the work for equality identified by Einarsdóttir (2003). The demand for a historical and localized specificity has always to be central though to avoid what Lykke has coined the 'Danish situation', i.e. "a slippery slope towards a discursive situation, where gendered power differentials can be "legitimately" ignored in favor of an exclusive focus on other diversity markers" $(2003,56)$, hence, she has stressed that gender power has to be a central theme in intersectionality approaches, although never stipulated a priori (2003, $53)$.

\section{TRADITIONAL EQUALITY WORK AND POSSIBILITIES OF EXPANSION}

As intersectional approaches and the focus on multiple inequalities are a continuation and a response to gender equality policies, it is important to explore the connections between the two. The Convention on the Elimination of All Forms of Discrimination against Women (CEDAW), adopted in 1979 by the UN General Assembly, is often referred to as an international bill of rights for women. Another key governmental commitment to women is the UN Beijing Platform for Action (1995). Overall, the history of gender equal policy in the Western world has been divided into three overlapping chronological steps; equal treatment, positive action or affirmative action, and gender mainstreaming (GM) (Rees 2002, Woodward 2004, Einarsdóttir 2002, $2003)$. It can be argued that equal opportunity work is currently moving on to a fourth stage, where the focus is no longer on gender inequalities in isolation, but on equality and diversity, a policy which can be summarized with the slogan "equality for all" (Walby 2004, Woodward 2004, Shaw 2005, Squires 2005, Verloo 2006, YuvalDavis 2006). For that Article 13 of the Amsterdam Treaty from 1999, is of vital importance, as it provides a legal basis for six or eight specific grounds on which discrimination is prohibited (Article 13 EC). Furthermore, in order to demonstrate the commitment of non-discriminatory agenda the EU has designed the year 2007 as the European Year of Equal Opportunities for All. The proposal claims that attention will be paid to multiple discriminations, but simultaneously, an explicit gender focus will be enacted (2007 - European Year of Equal Opportunities for All).

But what does the goal of equality for all, represent and how can it been accomplished? Verloo (2006) distinguishes between two ways in which the practical equality work can be dealt with. The first model, she suggests, is to expand GM to encompass intersectionality, i.e. by screening, or deepening the various GM tools, so that they are not biased to any axis of inequality. The necessary precondition is advanced knowledge and experience with GM, otherwise, it jeopardize that the gender category will be dismissed. The second model is to develop forms of comprehensive (or 'equality') mainstreaming, such as race/ethnicity mainstreaming, sexuality mainstreaming, etc. This would pay fuller attention to each specific case, but perhaps be at the cost of structural analysis of interconnections (Verloo 2006:223), and with the risk of enhanced departmental thinking. Alternatively, Squires (2005) suggests a model of "deliberative democracy", a democratic inclusion to deal with "equality 
and diversity". "The basic impulse behind deliberative democracy is the notion that people will modify their perceptions of what society should do in the course of discussing this with others." What it offers theories of GM "is a concern with the quality and form of engagement between citizens and participation forums, stressing in particular the importance of political equality and inclusivity of unconstrained dialog" (Squires 2005:380-81). Related to that is Yuval-Davis (1997) model of transversal politics, which is based on the idea of a dialog of "rooting" and "shifting" where "each participant ... brings with her the rooting in her own membership and identity; but at the same times tries to shift in order to put herself in a situation of exchanged with women who have different membership and identity" (Yuval-Davis 1997,130).

We will now move on to see how various empirical examples from Iceland fit in with the different models described, and discuss the problems and potentialities of the Icelandic approach in light of the political context as well the marginalization of feminist knowledge on gender issues and intersectionality (Einarsdóttir 2002, YuvalDavies 2006).

\section{THE EXPANSION OF EQUALITY WORK IN ICELAND}

"The expansion of the equality concept" is a key term in our study, but it is only a "working tool" and we are aware of its limitation. The word "equality", of course, means equality for all; therefore it is contradictory to speak of "expansion" when discussing equality of other groups than women and men. Woodward (2004) however, has pointed out, that in Europe equal opportunity really meant equal opportunity of women. That has certainly been the case in Iceland as well, as demonstrated in names of institutions like "The Equal Rights Office" [Is. Jafuréttisstofa], but its role is defined in article 3 of the current equal rights laws, Act on the Equal Status and Equal Rights of Women and Men, No. $96 / 2000$. The discourse on the need to expand the notion of equal rights and equal opportunities also to include equal rights of various minority groups is relatively new in Iceland. It is structured on the equality principle of the Icelandic Constitution from 1995, which explicitly prohibits discrimination based on sex, religion, opinion, national origin, race, color, property, birth, or other status. In addition, the Constitution includes a paragraph on equal rights of men and women (Act. No. 97/1995, Article $65)$. Changes in this direction, which will be discussed later, have already occurred within the University of Iceland and the city of Reykjavík.

\section{EQUAL RIGHT WORKERS VIEW ON THE} EXPANSION OF THE EQUALITY CONCEPT Interviews with eleven equal rights workers in Iceland carried out from 2004-2006, reveal a tension and mixed feelings towards expansion of the equality concept. The equality workers, all women, worked for the state, local governments or private companies. Only a few were already working on broader diversity issues but the majority was gender equality specialists. Many expressed the concerns that if already limited funding and human resources, devoted to equality work, were to be split up between various minority groups, little progress would be made at any level, and they feared that gender equality issues would be set aside (Thorvaldsdóttir 2005). An interviewee from the skeptical group had this to say:

“This expansion, its coming ... but we have very limited possibilities to deal with it ... I feel that we have way too far to go in terms of gender dis[crimination]... gender equality, to be able to deal with other forms of equality issues yet." 
This view, which probably is grounded on practical concerns, highlights the emerging "political competition" (Lykke 2005, Verloo 2006) or hierarchizasion of inequalities. Moreover, it is a reminiscence of the now legendary argument, that was embedded in Marxist ideology, where class inequalities were prioritized above everything else, on the grounds that only when those issues had been solved, other and less important inequality concerns could, like the women's question, be dealt with.

In opposition is the view of an equality worker who openly favored expansion.

"We can't simply decide that the equality concept, only applies to the equality struggle of a particular group. ... I also believe that prejudices, which different groups are exposed to, are in fact rather similar. Therefore, I believe that it would be more effective to develop it along the lines of the equality principle of the constitution."

Here the notion of specificity, and the need to acknowledge different kinds of differences, appears to be missing, in favor of "additive intersectionality", (Lykke 2005) where the various minority positions are viewed as separate structures and bounded entities that do not intra-act. Some questioned whether the "expansion" would be added on to the workload and budget of traditional equal rights workers, or if separate "diversity" officers who would specialize in equal rights issues of the various minority groups would be established (cf. Verloo 2006). An argument that has been used to legitimate the claim that all equality work should be on one hand, is that it would guarantee that all the knowledge and experience, which have been acquired during thirty years of official gender equality work, could be appropriated for the other equality work as well (Beveridge and Nott 2002, see Verloo 2006 and Shaw 2005). Some of the interviewees put a question mark there. One said: "I doubt, that the fact that I know how to work on equal right issues of men and women, make my specially qualified to work on issues that face other minority groups. Some is transferable, other is not."

A fundamental issue here is the very definition of equality work and what it should entail. At this point it is helpful to bear in mind the three stages of gender equality work, i.e. equal treatment, positive action and gender mainstreaming. One interviewee agreed with the principle that the equal right concept should be expanded, but she also expressed some doubts on how that could be worked out in praxis. To make her point she outlined two conflicting approaches. On the one hand is the "expansion of the equality concept". At this point, the focus is on the diverse disadvantage groups, which the policy should aim to serve, and the question really is, "the equality of whom?" The alternative approach, which she had been emphasizing in her own work, can be phrased as "a broader vision of equality", referring to the diverse sectors of society that equality work should be affecting, in praxis, gender mainstreaming. So instead of asking "the equality of whom?" the question is "how far, deep, and wide into various segments of society should equality work be reaching?"

In comparison, for the woman who was most firmly "pro-expansion" the most pressing issues at hand was the democratic principle that immigrants should be guaranteed access to basic information, regarding their rights and entitlement as new citizens of Iceland, which would enable them to actively participate both in civil and democratic society, such as exercise their right to vote and etc. A hugely important issue indeed - but it is on quite a different level than the "broader vision" outlined above. This aim really falls under the principle of equal treatment, while the former was clearly built on the principle of mainstreaming. That raises the important question whether each minority group needs to go 
through all the three stages in their own time. Maybe it is a simplification to imagine that because women have already reach the third stage, gender mainstreaming, all the other group can simply skip the first two steps, and fast forward to go directly to mainstreaming. By stating that, we are not proposing that the other minority groups should stay thirty years behind indefinitely, but rather acknowledging the fact that the different groups are situated differently, historically and contextually (Yuval-Davis 2006). Immigrants, as a distinct 'social category', have for instance, only existed in Iceland for about 20-30 years. Therefore, putting all the groups under one hat, expecting them to follow the same path, at the same pace, could be viewed as a simplification, but not as a useful strategy for equality for all.

\section{VOICES FROM MINORITY GROUPS}

It appears that emphasis on "cultural and political inequality rather than inequalities in distributional goods" (Squires 2005, see also Phillips 1999) or in Fraser's (1997) terms, the move from "redistribution to recognition" has resulted in increased hostility towards gender equality policies, even to the extent that feminists have been accused of "stealing" the equality concept.

This view was clearly presented at the conference Equality for all that was hosted by the City of Reykjavík Equal Rights Committee in 2006 where a representative from Samtökin '78 - The National Organization of Lesbians and Gay Men in Iceland, delivered a paper, entitled: "The oppressive tools of the Equal Rights Struggle." He stated:

"Women have built their own weapons in the equality struggle against White, Western, Middle Class Men - Straight [...] Women have obtained equality laws. Women have gained equal rights committees; Women have got Complaints Committee in Equal Status - weapons in the struggle for equality? Equality for whom? Has equality been monopolized? Just for some? Can it be that women's weapons are now used to beat up other minority groups? [...] When the equality concept is interpreted so narrowly that one group gets legally defined weapons to fight with, in the name of equality, it can create considerable injustice towards others. Because, those institutions that have been established in the name of equality, can often serve as tools of oppression for other groups in society, which are also struggling for human rights" (Eggertsson 2006).

An intersectional approach to a report on minority groups that was conducted in 2003 for the Reykjavik City Committee on Equal Rights further demonstrated some of the dangers to look out for. The spokespersons for the selected minority groups tended to look at the groups that they were representing as a separate unit that required separate equal rights actions and goals. In most cases gender differences within the groups were considered irrelevant. Thus a spokesman for the national organization of people with disability (which is an umbrella organization for 27 various specialized disability organization) claimed that he considered it almost offensive to ask about the effects of gender in relation to equal rights of the disabled, instead of focusing on the nature of the disability, which generally effected men and women the same (Magnúsdóttir 2003).

This male-centered point of view was seriously challenged in a theme issue of the feminist magazine Vera, entitled "Equality for everyone". It featured interviews with women who belonged to the three minority groups that had been in the forefront in the equality discourse in Iceland. The title of an interview with the lesbian couple, where one was also in a wheelchair: "Triple burden. To be 1) a woman, 2) a disabled and 3) a lesbian" (Thorgeirsdóttir 2004: 24) really sums up their argument and tan- 
gled the pragmatic view that being in a wheelchair, i.e. being disabled, always meant one thing only, regardless of other social positions.

\section{EXPANSION OF THE EQUALITY CONCEPT: THE CITY OF REYKJAVIK}

In 2003, Reykjavik City Committee on Equal Rights launched its new goal of "expanding the equality concept" to include equality of homosexuals, immigrants and people with disabilities in the city's equal right policy. And, a new giant step towards expansion was taken with the adoption of The City of Reykjavik's Human Rights Poli$c y$, on May $16^{\text {th }} 2006$.

"This policy is based on the principle of equality and aims to allow all persons to enjoy their human rights regardless of origin, nationality, skin color, religious and political beliefs, sex, sexual orientation, age, financial situation, heritage, disability, state of health or any other status. ... with special emphasis on the equal status of women and men. ... emphasis is placed on a coordinated vision for the benefits of city inhabitants, insomuch as many of them belong to more than one of the groups it covers."

Prior to the implementation of the new policy, a special task force examined the pros and cons of mainstreaming human rights issues (Conclusions of a Research group on mainstreaming human rights issues, 2005). In the process representatives and/or experts from the social groups in question were consulted. All of them favored expansion, and all stressed the importance of formally acknowledging the minority position of their respective groups. To complete the process, a forum was set up where members from all the groups gathered together to discuss and negotiate about the final outcome. That was possible for the first time that such an act of "deliberative democracy" (Squires
2005) was put into practice in Iceland. Thus, the city of Reykjavik has followed model one in Verloo's account (2006), i.e. to expand the mainstreaming of gender equality to include diversity and equality for all.

The outcome, The Human Rights Policy of the City of Reykjavik, was adopted just few days before local election in May 2006 where a Leftist/Central coalition, which had been governing the city for 12 years, was replaced by a Right/Conservative coalition. The Leftist/Central coalition had made some valuable achievements in terms of gender equality issues and the advancement of women within the city of Reykjavik. Shortly after the new government of the City came to office, the position of an Equality Officer was abandoned and replaced by a Human Rights Officer. These changes took place within a very short period of time or less than half a year, and without the extra finances needed for the enlarged task at hand. The appointment of a new Human Rights Officer in 2006 reflects a formal, legal understanding of the area, and neither gender expertise nor expertise on other social inequalities seems to have been prioritized. ${ }^{1}$

\section{EXPANSION OF THE EQUALITY \\ CONCEPT: THE CASE OF THE \\ UNIVERSITY OF ICELAND}

The University of Iceland has been in the forefront in expanding the equality concept in Iceland, and to some extent it served as a role model for the expansion within the city of Reykjavík. However, the University has a rather short history of organized equal opportunities work. A task force was established in 1996 and based on its recommendations the first Equal Rights Committee was established in 1997. Although the committee's letter of appointment stated that its task should be to work for equality "in a wider sense" the first equal opportunities action plan, valid from 
2000 to 2004, and updated in 2005-2009, focused explicitly on gender. ${ }^{2}$ Since then two new policies have been implemented, a Policy against Discrimination on the Grounds of Disability in 2003 and Policy against Discrimination in 2005. The latter refers to age, disability, health, gender, sexual orientation, religious and political beliefs, ethnicity, origin, color of skin and culture (The University of Iceland's Policy Against Discrimination 2005). The equal rights work at the University is now based on these three policy documents, and the official goal is diversity and equality for all. Those responsible for the equal rights work within the University are the Equal Rights Committee and the Equal Opportunities Officer (EOO), which is a part time position.

The gender equality action plans (20002004, and 2005-2009) are based on gender mainstreaming. In the general discourse, however, gender equality is framed in a formal, liberal, anti-discrimination approach and certain skepticism is expressed against positive action strategies. In spite of official declarations, it can be questioned whether GM has been implemented at the University (Halldórsdóttir 2004). Gender equality projects include a broad range of issues, such as; an effort to challenge the gender segregation in study fields, a database on women specialists, a report on gay and lesbian students, a plan to fight sexual harassment, and a detailed study of engendered opinions in placement committee decisions. ${ }^{3}$ None of these actions, however, have led to any changes in procedures, working processes, policy process etc., as the EC's definition on gender mainstreaming implies. Even if the current gender equality plan, (valid 2006-2009) is based on GM, there appears to be a backlash in some instances. The previous plan included, for example, a clause referring to GM in teaching, course literature and education, were this was relevant (chapter III). This clause was dropped out in the current ac- tion plan on the grounds that it violated the "academic freedom" of individual teachers. Hence, it can be questioned, whether the University of Iceland has ever moved beyond rhetoric or window dressing when it comes to gender mainstreaming (Verloo 2002:3).

\section{The Equal Opportunities Officer CASE AT THE UNIVERSITY OF ICELAND}

As for the City of Reykjavík, a preparatory working group preceded the extension of the equality concept at the University. Even if the interaction of multiple inequalities, the nature of different social divisions or the relationships between them were not conceptualized, gender issues were emphasized by the Chairman of the Equal Rights Committee launched the Policy Against Discrimination. ${ }^{4}$ When it really counts, however, this does not seem to be the University's official understanding of the equality concept. An interesting case that sheds a light on the issue is the appointment of an EOO in the spring 2005. In the announcement education in the field of "equality" was required and education in "gender studies" was preferable. The University ignored the Equal Rights Committee recommendation of a person with a background in gender studies and hired someone who lacked such education. Following from that a third applicant issued a complaint to the Althing Ombudsman [AO]. The case revolved around the exact definition of concepts used in the announcement, and not least, the relationship between "equality" and "gender equality" in the evaluation of applicants. The AO concluded in favor of the University and hence, their arguments, which will be accounted for below, have gained greater legitimacy and institutional support in Iceland. 5

The main argument of the University was that the primordial criteria according to which the applicants were assessed, was whether their education had covered 
'equality' issues. The criteria on education in 'gender studies' was seen as positive, or as a bonus, which only came into consideration when the primordial criteria (education on 'equality' matters) was fulfilled. It then had the same weight as other criteria mentioned in the announcement. Thus, gender expertise had the same significance as proficiency in written language and oral presentation, independency, abilities to collaborate, organizational skills and competence in human relations, in the comparison of applicants. 6 The term 'equality' was not explicitly defined, but validated with a reference to the recently adopted Policy against Discrimination. While the issue of gender equality was not addressed explicitly, it was stated that the equality concept had to be understood in a 'historical context' and that gender equality did no longer have a priority over equality of other minority groups.

Notwithstanding the preparations on behalf of working groups within the University, no attempt was made to differentiate multiple inequalities or to conceptualize relationships between them, for example how gender intersect with other inequalities. Furthermore, by placing gender studies at the same level as general competencies such as proficiency in written language etc. the Althing Ombudsman reveals that gender expertise is not recognized, even if the University still embraces gender mainstreaming in its gender equality action plan. This appears to be a vital flaw, because many scholars perceive gender expertise as a prime condition for a successful work on gender mainstreaming (Rees 1998, Verloo 2001, 2002). The University thus adopted Verloo's first model, along with its potential shortcomings. Intersectional understandings on how multiple inequalities intersect, while operating at many different levels simultaneously, were not grounded in academic research. Furthermore, strategies of GM were hardly fully developed within the University (Halldórsdóttir 2004). In an atmosphere of formal, liberal understanding of the equality concept "the expansion" came with the consequences that the gender dimension was ignored (Lykke 2003).

\section{CONCLUDING REMARKS}

How can the case of Iceland be understood in relation to recent theoretical debates on tensions, problems and possibilities regarding intersectionality and multiple inequalities (Lykke 2005, Squires 2005, Verloo 2006, Yuval-Davis 2006)? As stated in the beginning, the empirical data from Iceland provides an opportunity to bring together theory and praxis. The equal rights workers in Iceland can be seen as advocates for a traditional equality work. Even if some of them were positive towards expansion, most of them expressed tension and mixed feelings towards the process. They were concerned with the possible dilution of the gender dimension and they voiced their doubts on whether their expertise on gender issues was transferable to other inequality matters. In contrast, the voices of the different minority groups in Iceland reflected skepticism, and sometimes even outspoken hostility, towards gender equality work. Moreover, some expressed a strong resistance to acknowledge the validity of gender issues within their own group. Hence, clear signs of a 'political competition between inequalities' can be discerned between the groups.

At this point, let's reiterate Verloo's two models to deal with equality for all. The first one is supposed to expand gender mainstreaming to encompass multiple inequalities, while the second one, aims to develop forms of comprehensive, or 'equality' mainstreaming, for each of the inequalities (2006). The expansion of the equality work underway at the University of Iceland as well as the City of Reykjavík appears to be following Verloo's first model. The conceptualizations of the equality concept reveal that gender and gender expertise has 
tended to be downgraded in the name of equality for all. The different inequalities now "share institutional spaces" (Walby 2004), and an overreaching "one size fit all” equality strategy (Verloo 2006). Despite some ambitious gender equality projects at the University, gender mainstreaming has hardly been implemented. Verloo argues that in order to encompass intersectionality, the various GM tools have to be screened so that they are not biased to one axis of inequality (2006). This has not been done in the University. The leap from a fragmentary GM policy to a diversity policy runs the risk of being a 'watered out version' of an already empty phrase (Woodward 2004, Walby 2004, Squires 2005, Shaw 2005). Lykke warns for "a slippery slope towards a discursive situation, where gendered power differentials can be "legitimately" ignored in favour of an exclusive focus on other diversity markers" (2003, 56). We are concerned that the University of Iceland might be at that point now.

In the City of Reykjavík, a phase of preparation, although a short one, preceded the move from gender equality to 'equality for all'. Prior to that, the city has been at the forefront in the work for gender equality and some valuable achievements have been made, especially in enhancing the position of women in leading positions. Even if the move from gender equality to 'equality for all' was based on a reflected consideration of the expansion, explicit conceptualizations of how different inequalities intersect were not developed. In that respect, we see similarities between the City of Reykjavík and the University. As regards the equality work, the City of Reykjavík seem to built on a fragmented understanding of GM, even if it seems to be more institutionalized than at the University.

We stated in the beginning that intersectionality appears to be a promising point of location, from where the complicated process of rethinking equality work for all could start. If we expand from Einarsdóttir (2003) configuration of the three pillars needed for a successful gender equality work, it can been argued that members from two of the pillars, i.e. policy makers and people from various grassroots movements, were involved in the process of policy making at some level in both the City of Reykjavík and the University. However, feminist knowledge on how multiple inequalities inter-/ and intra-act was missing (Lykke 2005, Verloo 2006). Thus, the most important condition for intersectionality politics had not been conveyed on to the political level in Iceland. So the third pillar in Einarsdóttir configuration, expertise based on academic research is missing (Einarsdóttir 2003). Yuval-Davies claims that a dialogue between the named actors can be seen a starting point for alliances across boundaries of difference, or 'transversal' politics (Yuval-Davis 1997), and that such a lack of communication appears to be one of the main hindrances towards a successful equality work for all (Yuval-Davis 2006). The emerging 'equality for all' policy in Iceland is taking place in a historical and social context similar to the 'Danish situation' (Lykke 2003), where gender relations are embedded in a liberal, individualistic, gender-skeptical atmosphere, and where feminist knowledge is not recognized. Lykke's alert that gendered power differentials can be "legitimately" ignored in favor of an exclusive focus on other diversity markers" seems to apply to Iceland. The Icelandic case reveals, paradoxically, that there are reasons to be concerned that the emerging 'equality for all' policies will result in less equality, not only for women, but for all.

\section{Noter}

1. The person hired is a lawyer without formal background or qualifications in gender equality or diversity issues but has served as Iceland's first Ombudsman for children. 
2. See http://www.jafnretti.hi.is/page/jafnrettisaaetlun2000-2004 (in Icelandic) and the website of the Equal Rights Committee at the University of Iceland: www.jafnretti.hi.is.

3. See the website of the Equal Rights Committee, http://www.jafnretti.hi.is/id/1012592

4. The chairman of the Committee, a gay man, emphasized that gender issues would still be important in the new context of 'equality for all' on the Equal Rights Committee's Celebration Festival on November 24th 2005.

5. The Conclusion of the Althing Ombudsman in case no. 4469/2005. http://www.umbodsmaduralthingis.is.

6. The applicant who brought a complaint to the $\mathrm{AO}$ was dyslexic, and explicitly stated that in the job interview (expressed in a personal email to the authors $17 / 8$ 2006). The emphasis on proficiencies in written language can therefore be seen as rather paradoxical, not least in the light of the weight put on equality of minority groups and the repeated references to the Action Plan against Discrimination.

\section{REFERENCES}

\section{- The Amsterdam Treaty article 13}

http://eurlex.europa.eu/en/treaties/dat/12002 E/htm/C_2002325EN.003301.html\#anArtl4

- Brah, Avtar \& Phoenix, Ann, (2004) "Ain’t I A Woman? Revisiting Intersectionality." Journal of International Women's Studies, 5(3): 75-86.

- Butler, Judith, (1990/1999) Gender Trouble. Feminism and the Subversion of Identity. New York, Routledge.

- The City of Reykjavik's Human Rights Policy, May $16^{\text {th }}$ 2006. http://www.reykjavik.is/DesktopDefault.aspx/tabid-1122/1712_read-2428

. Collins, Patricia Hill, (1998) "It's all in the Family: Intersections of Gender, Race, and Nation." Hypatia, 13(3): 62-82.

- Conclusions of a Research groups on mainstreaming human rights issues. (2005) Reykjavik, December $10^{\text {th }}$. [An unpublished paper.]

. Crenshaw, Kimberlé, (1994) "Intersectionality and Identity Politics: Learning from Violence against Women of Color.” In Martha Albertson Fineman, Rixanne Mykitiuk, Ed., The Public Nature of Private Violence. New York, Routledge, 178-193.

. Eggertsson, Vidar, (2006) "Kúgunartæki jafnréttisbaráttunar." ["The oppressive tools of the Equal right struggle."] Paper presented at the City of
Reykjavik Equal Rights Committee conference Equality for all. Reykjavik, February $17^{\text {th }}$.

- Einarsdóttir, Thorgerdur, (2002) "Jafnrétti án femínisma, pólitík án fræda? Um ?áttaskil í íslenskri jafnréttisumrædu." [ "Equal rights without feminism, politics without academic studies."] Ritid, 2: 9-36.

. Einarsdóttir, Thorgerdur, (2003) "Challenging the Slow Motion of Gender Equality - The Case of Iceland." Presented at Gender and Power in the New Europe, the $5^{\text {th }}$ European Feminist Research Conference, August 20-24. Lund University, Sweden.

\section{- 2007-European Year of Equal Opportunities for} all

http://ec.europa.eu/employment_social/equality2007/index_en.htm

- Fraser, Nancy, (1997) Justice Interruptus. New

York, Routledge.

- Halldórsdóttir, Erla Hulda, (2004) Stada og ?róun jafnréttismála 1997-2002. [The Status and Development of Equality issues.] Reykjavík, The Equal Right Committee at The University of Iceland.

- Knapp, Gudrun-Axeli, (2005) "Race, Class, Gender. Reclaiming Baggage in Fast Traveling Theories." European Journal of Women's Studies, 12(3): 249-265.

- Lykke, Nina, (2003) "Intersektionalitet - ett använbart begrepp för genusforskningen." Kvinnovetenskaplig tidskrift, 1: 47-55.

- Lykke, Nina, (2005) "Nya perspektiv på intersektionalitet. Problem och möjligheter." Kvinnovetenskaplig tidskrift, 2-3: 7-17.

- Lög um jafna stödu og jafnan rétt kvenna og karla (96/2000) [The Act on the Equal Status and Equal Rights of Women and Men.] Act No. 96 of 22 May 2000. http://www.althingi.is/altext $/ 125 / \mathrm{s} / 1311 . h t m l$

- Magnúsdóttir, Berglind Rós, (2003) Minniblutahópar, kynferdi og jafnrétti. [Minority groups, gender and equality.] A report for the Reykjavik City Committee on Equal Rights, Reykjavik. http://www.reykjavik.is/upload/files/Minnihlutahópar\%20-

\%20\%20kynferdi\%20og\%20jafnrétti.pdf

- Phillips, Anne, (1999) Which Equalities Matter? Cambridge, Polity Press.

- Rees, Teresa, (1998) Mainstreaming Equality in the European Union. London, Routledge.

- Rees. Teresa, (2002) “Gender Mainstreaming: Misappropriated and Misunderstood?" Paper presented to the Department of Sociology, University of Sweden.

http://www.sociology.su.se/cgs/ReesPaper.doc 
- Stjórnarskrá l?dveldisins Ísland nr. 33/1944, stjórnskipunarlög nr. 97/1995, 65. gr. [The Constitution of the Republic of Iceland No. 33/1944, cf. Constitutional Act No. 97/1995, Article 65.] http://www.althingi.is/altext/stjt/1995.097.html . Shaw, Jo, (2005) "Mainstreaming Equality and Diversity in European Union Law and Policy." Current Legal Problems, 58: 255-312.

. Squires, Judith, (2005) "Is Mainstreaming Transformative? Theorizing Mainstreaming in the Context of Diversity and Deliberation." Social Politics, 12(3): 366-388.

. Thorgeirsdóttir, Elísabet, (2004) "?refalt ómark ad vera lkona, 2fötlud og 3lesbía." ["Triple burden, to be 1 a woman, 2 a disable and 3 a lesbian.” An interview with Jóhanna Björg Pálsdóttir and Lana Kolbrún Eddudóttir.] In Vera, 3: 24-27.

. Thorvaldsdóttir, Thorgerdur, (2005) "Jafnréttishugtakid - of vítt eda of ?röngt? Um

- Verkefni og markhópa í íslensku jafnréttisstarfi.” ["The equality concept - too wide or too narrow? Projects and target groups of equality work in Iceland."] Rannsóknir i félagsvisindum VI. Ed. Úlfar Hauksson. Reykjavík, Félagsvísindastofnun Háskóla Íslands, 323-331.

- The University of Iceland's Policy against Discrimination. (2005) Passed at the University General Forum, February 18.

Verloo, Mieke, (2001) Another Velvet Revolution? Gender Mainstreaming and the Politics of implementation. IWM Working Paper No. 5/2001, Vienna.

- Verloo, Mieke, (2002) "The Development of Gender Mainstreaming as a Political Concept for Europe." Conference Gender Learning, Leipzig 68 September.

- Verloo, Mieke, (2006) "Multiple Inequalities, Intersectionality and the European Union." European Journal of Women's Studies, 13(3): 211-228. -Walby, Sylvia, "Gender mainstreaming: Productive tensions in theory and practice." Contribution to ESRC Gender Mainstreaming Seminars, 2003-4. -Woodward, Alison E., (2004) "Diversity? The Europeanization of difference and the influence of the United States on conceptualizations of equality policy." Background paper for Inclusion and Exclusion in Contemporary European Societies IUC, Dubrovnik, Croatia April 19-23.

- Yuval-Davis, Nira, (1997) Gender and Nation. London, Sage.

. Yuval-Davis, Nira, (2006) "Intersectionality and Feminist Politics." European Journal of Women's Studies, 13(3): 193-2009.

\section{ABSTRACT \\ The article explores recent theoretical debates on intersectionality and gender equality. It addresses problems and potentialities of the emerging 'equality for all' policies, drawing upon empirical examples from equality work in Iceland (equal opportunities workers, mi- nority groups, the City of Reykjavik and the University of Iceland). Practical equality work will be viewed through the lenses of fem- inist theories on intersectionality and related to wider political context and gender dis- course in Iceland. These empirical examples are analyzed in light of the theoretical back- ground, in particular, the different models, discussed by Verloo (2006) and Squires (2005) regarding how practical equality work can be dealt with. By bringing together theory and praxis, light will be shed on some of the problems and possibilities that are bound up with the different approaches.}

Thorgerdur Einarsdóttir, Dr.fil, Associate Professor of Gender Studies, Faculty of Social Sciences, University of Iceland

Thorgerdur Thorvaldsdóttir, MA, PhD-student of Gender Studies, Faculty of Social Sciences, University of Iceland 